\title{
Homossexualidade, religião e direitos: a controvérsia sobre 0 Estatuto da Família no Brasil'
}

\author{
Renata Reverendo Vidal Kawano Nagamine \\ Pós-doutoranda pela Universidade Federal da Bahia, Brasil \\ renagamine@gmail.com \\ Olívia Alves Barbosa \\ Pesquisadora do Centro Brasileiro de Análise e Planejamento, Brasil \\ olivia.a.barbosa@gmail.coml
}

Resumo Neste artigo, propomos analisar as estratégias discursivas e escolhas normativas de deputados federais formal ou ideacionalmente ligados às assim chamadas 'igrejas tradicionais' no debate público acerca do projeto de lei $\mathrm{n}^{\circ}$ 6.583, de 2013, conhecido como Estatuto da Família. Observamos que as disputas entre essas forças e atores políticos seculares têm encontrado um terreno fértil na Câmara dos Deputados. Pressupomos que as diferenças, as potencialidades e o debate acerca do Estatuto da Família permitem refletir sobre o lugar dos direitos e da religião no espaço público brasileiro. Recorre-se a uma literatura antropológica sobre religião para compreender o estatuto do religioso no espaço público brasileiro e, para analisar as falas coletadas, também são usados escritos recentes de Nadia Urbinati sobre o tema, a qual o discute desde o domínio da teoria política.Trata-se de um artigo resultante de pesquisa qualitativa, que empregou como técnicas para coleta de dados a pesquisa documental e a revisão bibliográfica.

Palavras-chave: orientação sexual, direito de família, democracia, direitos humanos, corte judicial.

1 Este artigo se baseia em dissertação de mestrado de Olívia Alves Barbosa, elaborada no Programa de Pós-Graduação em Direitos Humanos da Faculdade de Direito da USP e defendida em 2017. Em sua elaboração nos beneficiamos, sobretudo, das discussões travadas no âmbito do projeto temático "Religião, direitos e secularismo: a reconfiguração do repertório cívico no Brasil contemporâneo", desenvolvido no Centro Brasileiro de Análise e Planejamento (Cebrap), com financiamento da Fundação de Amparo à Pesquisa do Estado de São Paulo (Fapesp). Por fim, mas não menos importante, registramos nosso especial agradecimento a Aramis Luis Silva e Juliana Belangero, bem como aos pareceristas anônimos que avaliaram este artigo e que nos apontaram fragilidades e nos deram sugestões precisas. 


\section{Introdução}

Neste artigo propomos analisar, à luz de uma literatura em ciências sociais, as falas, estratégias discursivas e escolhas normativas de deputados federais ligados às igrejas cristãs de maior projeção pública no Brasil, como a Católica, a Assembleia de Deus e a Universal, no debate acerca do projeto de lei $n^{\circ} 6.583$, de 2013, popularmente conhecido como Estatuto da Família. Sucintamente, o problema de que nos ocupamos, aqui, constituise quando políticos que se autodefinem cristãos são democraticamente eleitos e, tendo assento na Câmara dos Deputados ou no Senado Federal, manifestam opiniões e posições que se sabe ou se suspeita serem informadas por preceitos religiosos. Eles afrontam, com isso, o princípio do Estado laico? Como julgar a sua participação no debate público em uma democracia constitucional, isto é, em uma forma de governo fundamentalmente comprometida com a pluralidade (Marzano; Urbinati, 2013; Urbinati, 2014), como é o caso do Brasil contemporâneo?

No Brasil, a participação de atores políticos religiosos no debate público sobre direitos tem enfocado temas como a liberdade de abortar e as demandas de gays e lésbicas por direitos de conjugalidade e de parentalidade, também referidos por "direitos familiais" (Mello, 2005). No caso dessas demandas, a família, o casamento e a criança têm suscitado a ansiedade de instituições, líderes e fiéis cristãos, sendo objeto de disputa deles com o movimento LGBTT (lésbicas, gays, bissexuais, travestis e transexuais).

Desde a regulação da união estável entre pessoas do mesmo sexo pela decisão do Supremo Tribunal Federal (STF), em 2011, e a instituição do 'casamento gay'2 ou do ‘casamento igualitário' pelo Conselho Nacional de Justiça (CNJ), em 2013, o debate público sobre direitos familiais de gays e lésbicas tem contraposto instituições e lideranças religiosas ao movimento LGBTT e defensores de direitos humanos de gays e lésbicas no Brasil. Pressupomos, neste artigo, que as demandas de gays, lésbicas, bissexuais, travestis e transexuais por direitos familiais são desestabilizadoras e têm sido transformadoras das convenções sociais acerca da família e das suas relações com dissidências da norma cultural da heterossexualidade (Weston, 1997), na medida em que essas convenções excluem a homossexualidade e as dissidências em matéria de identidade de gênero da família.

Optamos, então, por analisar o embate, que buscamos alcançar analiticamente pela categoria “controvérsia”. Essa nossa opção implica uma ênfase nos polos em um conflito e, em alguma medida, a sua construção como blocos homogêneos, ainda que reconheçamos a sua heterogeneidade no plano da ontologia. No Brasil, como em outros países, com destaque para os Estados Unidos $^{3}$, há dissidências entre instituições e lideranças cristãs

2 Neste artigo usaremos aspas duplas para categorias analíticas e aspas simples para as categorias êmicas.

3 Nos Estados Unidos, além da emergência precoce de 'igrejas inclusivas', tem curso um processo de transformação de denominações tradicionais, como a Metodista e a Presbiteriana, em instituições acolhedoras da diversidade sexual e de gênero, inclusive com a revisão de disposições que definiam o matrimônio religioso como uma união entre um homem e uma mulher para abrir a possibilidade de celebração de uniões homossexuais. 
no que se refere à aceitação sem transformação da homossexualidade, como é o caso das 'igrejas inclusivas'4 no campo protestante, da Igreja Anglicana, de lideranças das chamadas 'igrejas tradicionais' ${ }^{5}$, que se distinguiriam por sustentarem uma postura de acolhimento ${ }^{6}$ e reconhecimento da justiça das demandas por direitos, como o célebre padre Fábio de Melo (Globo Play, 2017; Terra, 2017).

Sem negligenciar a heterogeneidade de instituições e lideranças religiosas, de um lado, e do movimento LGBTT, de outro, observamos que, no Brasil, os embates entre esses dois grupos de atores políticos têm encontrado um terreno particularmente fértil na Câmara dos Deputados. Essa disputa concentrou-se, muito recentemente, nos contornos, isto é, dos limites do que é família para fins de direito no Brasil a propósito do projeto de lei $n^{\circ}$ 6.583, de 2013, ou Estatuto da Família. A influência de atores políticos religiosos no debate sobre o Estatuto da Família na Câmara dos Deputados recoloca, assim, em discussão as relações entre religião, direitos e secularismo na democracia brasileira.

$\mathrm{Na}$ primeira seção deste artigo, apresentamos alguns aspectos histórico-antropológicos das ideias de laicidade e secularismo no Brasil. O propósito dessa econômica retomada da literatura sociológica e antropológica sobre o tema no contexto brasileiro é iluminar a discussão que pretendemos efetuar sobre o lugar da religião no país a partir de elementos empíricos. Depois, recuperamos falas de deputados federais enunciadas no debate sobre o Estatuto da Família na Câmara ${ }^{7}$. Nesse debate buscamos as produções discursivas de deputados favoráveis e contrários à proposição mais sensível do Estatuto, que é a restrição da noção de entidade familiar para fins de direito, isto é, de proteção estatal à unidade doméstica formada por um homem e uma mulher ${ }^{8}$. Com isso pretendemos evidenciar as

4 Trata-se de uma categoria êmica que é empregada para designar igrejas cristãs que surgem no âmbito do protestantismo histórico nos anos 1960, no Oeste dos Estados Unidos, com o intuito de conciliar homossexualidade, travestilidade e transexualidade com o cristianismo e que adotam uma postura de apreciação da diversidade sexual e de gênero. No Brasil a categoria engloba, principalmente, as seguintes denominações: Igreja da Comunidade Metropolitana (ICM), Igreja Cristã Contemporânea (ICC), Comunidade Cristã Nova Esperança (CCNE) e Cidade de Refúgio (CR).

5 Trata-se de uma categoria êmica que é correntemente empregada em congregações e por lideranças do campo inclusivo no Brasil para designar instituições religiosas longamente estabelecidas no país das quais elas se distinguiriam pela apreciação positiva da diversidade sexual e de gênero. Sub-repticiamente ou, conforme a situação, manifestamente, a categoria 'igrejas tradicionais' também é usada para designar instituições religiosas, como a Igreja Católica, a Congregação Cristã do Brasil, a Assembleia de Deus, a Igreja Universal e a Igreja Batista, como 'homofóbicas' e 'transfóbicas'.

6 Dados coletados em pesquisa de campo feita entre outubro de 2015 e junho de 2016 na igreja Cidade de Refúgio de São José do Rio Preto e na Igreja da Comunidade Metropolitana de São Paulo.

7 Para mapear as falas dos deputados federais assistimos a 40 horas de audiências públicas realizadas na Comissão Especial destinada a proferir parecer ao PL 6.583/2013 das sessões legislativas de 2014 e 2015. Os vídeos dessas audiências estão disponíveis ao público no portal da Câmara dos Deputados.

8 “Art. $2^{\circ}$ Para os fins desta lei, define-se entidade familiar como o núcleo social formado a partir da união entre um homem e uma mulher, por meio de casamento ou união estável, ou ainda por comunidade formada por qualquer dos pais e seus descendentes" (BRASIL, 2013a). 
estratégias discursivas que esses deputados apresentam para legitimar ou justificar suas posições e visões no debate público, com foco nos usos que efetuam das ideias de laicidade e secularismo. Nesta seção, retomamos alguns elementos da literatura antropológica sobre religião para aprofundar sua análise enfrentando algumas questões normativas postas pelo problema, entre as quais a de que a sociedade brasileira é, no que concerne a temas como os direitos de gays e lésbicas e a legalização do aborto, uma sociedade monorreligiosa. Para pensar normativamente, recorremos à recente contribuição da teórica política italiana radicada nos Estados Unidos Nádia Urbinati à discussão sobre a presença pública da religião em democracias constitucionais. Embora o diálogo construído aqui entre antropólogos e teóricos políticos dedicados a discussões normativas possa causar espécie, ele nos pareceu útil para pensar moralmente o problema de que nos ocupamos, sobretudo, pelo que Urbinati (2013) denomina de laicité en reverse, ou o fenômeno segundo o qual instituições e atores políticos exploram a laicidade para ampliar a presença do religioso na esfera pública.

\section{Sentidos de laicidade e secularismo no Brasil}

No Brasil, a laicidade ${ }^{9}$ está consagrada no artigo 19, inciso I, da Constituição Federal, que determina a separação entre Estado e igreja. Há quem entenda (Zylbersztajn, 2012) que ela ainda compreende um conjunto de direitos constitucionais, entre os quais a forma democrática de governo, a liberdade religiosa e a igualdade. Se há algum consenso acerca da necessidade e legitimidade da separação e mesmo em torno da forma democrática, da liberdade religiosa e da igualdade como conteúdos da laicidade, os sentidos e os termos dessas categorias - em especial, de laicidade, liberdade religiosa e democracia - são disputados. Condições particulares teriam contribuído para a construção de um Estado que se define como laico e de uma ideia particular de secularismo no Brasil. Essa construção tem merecido a atenção de uma literatura sócio-antropológica dedicada ao estudo do fenômeno religioso no país.

Entre esses estudiosos, a antropóloga Paula Montero (2006, 2012, 2013) tem pensado a religião na esfera pública brasileira em perspectiva histórico-antropológica e em "controvérsias públicas" atuais. Na primeira linha, Montero (2006) argumenta que o catolicismo estabeleceu uma hegemonia entre nós por ter logrado se transfigurar de religião em cultura. Essa sua hegemonia estaria, ao seu turno, parcialmente relacionada com a construção da estrutura do Estado brasileiro em relação ao regime do padroado.

Segundo Montero (2006), o regime do padroado teria por característica a sobreposição dos aparelhos burocráticos estatal e religioso, os quais seriam operados conjuntamente para controlar os súditos e o território. Em seu entender, essa justaposição teria beneficiado tanto o Estado quanto a Igreja Católica: a Igreja pôde ser parte na construção do Estado nacional brasileiro, colocando-se, assim, em posição de controlar

9 Para uma discussão dogmática do tema, ver Pinheiro (2008) e Zylbersztajn (2012). 
diferentes aspectos da vida cotidiana na sociedade brasileira com base na legitimidade da ideia de 'credo nacional'; o Estado brasileiro, ao seu turno, apropriou-se do catolicismo e da máquina católica para consolidar o sentimento de unidade nacional e assegurar a sua soberania por todo o território (Montero, 2013). Em contrapartida, nesse regime a Igreja se mantinha subordinada ao Estado e distante do Vaticano. Esse arranjo de forças teria, por isso, debilitado a Igreja Católica brasileira, que acabou ficando com um número escasso de padres, pouca comunicação com Roma e parcos recursos econômicos. Sua fragilidade teria aberto caminho para a separação entre Igreja e Estado, que contou com a ação da própria hierarquia católica.

Embora a secularização do Estado tenha sido incentivada, e não combatida, pela Igreja no Brasil, sua disposição comportaria algumas nuances. Durante a Constituinte de 1890, a Igreja Católica se posicionou de duas formas: propôs uma estrutura autônoma em relação ao Estado e buscou inserir valores cristãos na Carta Constitucional. Na história do Brasil, ela teria contribuído, destarte, de duas maneiras para a construção de uma 'comunidade nacional': durante o Império, participou da estrutura política do Estado e lhe conferiu fundamentos éticos, enquanto, com a proclamação da República, concentrou-se na consolidação de uma sociedade civil atuante. Esse aspecto tende ser negligenciado na discussão sobre laicidade, secularismo e liberdade religiosa em abordagens estritamente jurídicas da religião, que não dão conta da permanência do religioso como moralidade e, portanto, como gramática a ser acionada por agentes na esfera pública. Para Montero (2006), no entanto, tal quadro histórico pode explicar, ao menos em parte, por que a laicidade nunca produziu, no Brasil, uma doutrina política que considerasse ilegítima a atuação política da Igreja Católica e sua manifestação no espaço público.

Pensando na Constituição de 1988, a formação histórica do Estado brasileiro e a de suas relações com a Igreja, descritas por Montero (2006), elucidariam por que os brasileiros entendem a laicidade não como a negação da religião pelo Estado ou seu afastamento do espaço público, mas como uma garantia de acesso igualitário de todas as religiões a ele. Laicidade, entre nós, seria, em outras palavras, pluralidade religiosa, não ausência de religião no espaço público. Trata-se, enfim, de um arranjo ou uma percepção social singular das relações entre religião e espaço público, a distinguir a configuração brasileira, por exemplo, daquela que se conformou em países como França e Turquia, nos quais a retirada da religião do espaço público teria sido patrocinada pelo Estado (Marzano; Urbinati, 2013).

$\mathrm{Na}$ configuração brasileira, ser religião significa ter legitimidade no espaço público e merecer proteção estatal em relação a outras religiões. Por isso, as disputas centradas no secularismo em parte se deslocam da relação entre religião e espaço público para a própria definição do que é, e, por conseguinte, do que não é, religião, sendo comum atores políticos religiosos agenciarem essa categoria para qualificar de 'seitas' práticas religiosas que consideram ilegítimas. Outro efeito importante do modo como as relações entre Igreja e Estado se estruturam no Brasil é que muitos sentidos e valores herdados do Cristianismo continuam presentes no nosso imaginário (Montero,2012). Porsua presença se aceita,segundo 
Montero (2012), tratar do bem comum em termos de preservação dos laços comunitários, tradição e direitos naturais. Isso não significa que tais termos não sejam acionados em outros contextos locais, mas que eles não necessariamente têm, nesses contextos, a mesma ressonância e o mesmo potencial que têm mostrado no Brasil. Pensamos, aqui, no potencial retórico de termos como tradição e, principalmente, direitos naturais porque um aspecto interessante do debate em torno do Estatuto da Família na Câmara e na sociedade brasileira, de um modo geral, têm sido os esforços de atores políticos religiosos por ressignificá-los, reclamando um lugar fundamental neles para o cristianismo.

No caso dos evangélicos no Brasil, essa reclamação tem importância por possibilitarlhes, ao mesmo tempo, (i) contestar o lugar privilegiado da Igreja Católica em relação ao Estado e ao direito, (ii) inserir-se em uma tradição precedente à sua própria ascensão histórica e (iii) formar alianças com outras denominações. Em linha com os argumentos de Montero (2012), o antropólogo Emerson Giumbelli (2014) também afirma que o catolicismo foi historicamente considerado a religião dos brasileiros e, em parte por força da construção da naturalidade da sua presença pública, continua sendo facilmente assimilado pela ideia de cultura nacional. Para Giumbelli (2014), as religiões afro-brasileiras nunca conquistaram, ao seu turno, um número expressivo de adeptos declarados, mas têm presença importante na produção cultural da nacionalidade brasileira, o que lhes confere um lugar complementar ao catolicismo. Uma diferença importante dos evangélicos em relação a esses dois grupos seria, então, que eles não podem apelar à história ou à tradição para justificar sua presença no espaço público. Para consolidar sua posição como cultura pública, eles buscam visibilidade em todas as esferas da vida, através de ações que visam a ocupação de posições e proliferação de referências (Giumbelli, 2014).

Nesse sentido, apesar da contínua influência da Igreja Católica no desenho institucional do Estado e na sociedade brasileira, a ascensão evangélica das últimas décadas enfraqueceu, para Giumbelli (2014), a imagem do Brasil como "nação católica". Isso decorreria, por exemplo, do crescimento das denominações protestantes e do seu modo de intervir no espaço público, com efeitos importantes na cena política nacional. Em linha com essa estratégia, evangélicos têm buscado, por exemplo, ocupar grandes meios de comunicação e cargos nos Poderes Legislativo e Executivo. A Frente Parlamentar Evangélica no Congresso Nacional (FPE), criada em 1993, é parte dessa estratégia. Reunindo, atualmente, $188^{10}$ deputados federais de 23 legendas partidárias ${ }^{11}$, ela tem grande influência nas votações e poder de barganha na Câmara. Já a Frente Parlamentar Mista Católica Apostólica Romana conta com 200 deputados signatários. Dado que 70 deputados federais são membros das duas frentes parlamentares, não é descabido pensar

10 Relação de membros das Frentes Parlamentares disponível no site da Câmara dos deputados em: $<$ http://www.camara.leg.br/internet/deputado/frenteDetalhe.asp?id=53658> . Acesso em: 01 dez. de 2016.

11 Segundo o Censo 2010, os evangélicos representam 22,2\% da população, percentual que aumentou $61 \%$ em relação às duas décadas anteriores. Em função desse crescimento, uma nova geração de políticos teria passado a ter sustentação de suas igrejas, mudando o padrão de representação. 
que temas construídos como sendo moralmente relevantes aos cristãos, como é o caso das demandas de gays e lésbicas por direitos, têm proporcionado a união de católicos e evangélicos, uma aliança que tende à instabilidade em outros temas, por exemplo, quando se trata da presença de símbolos religiosos em locais públicos, a existência de feriados nacionais consagrados a santos padroeiros e o acordo entre Brasil e Santa Sé.

A presença da Frente Parlamentar Evangélica é controvertida, podemos argumentar, em função de suas ações, como orações e a celebração de cultos no Congresso Nacional ${ }^{12}$, e da aparente influência da religião sobre seus posicionamentos públicos em matérias que são objeto de disputas. Já a Frente Parlamentar Católica atrai menos atenção, pensando a contrapelo, por ser menos coesa ou mais plural, embora parlamentares que a integrem sejam muito vocais, por exemplo, na defesa do Estatuto da Família. Apesar da força, sobretudo, da 'bancada evangélica' e de sua experimentada coesão no que se refere a direitos familiais e ou de gays e lésbicas, é interessante notar que sua legitimidade tem precisado ser justificada publicamente, o que pode assinalar uma consolidação do que chamaremos, aqui, de ethos constitucional ${ }^{13}$, tomado como um conjunto de fins e princípios estruturantes do corpo político em uma democracia constitucional.

$\mathrm{Na}$ atualidade, dois tipos de discursos são usados com esse propósito. No primeiro, são alegados preconceitos e limitações à sua atuação em função de privilégios conferidos ao catolicismo ou de intrusões que eles designam de laicistas. Esse discurso está, segundo Giumbelli (2014), em consonância com um segundo tipo. Neste, a religião aparece como base do pacto social (Giumbelli, 2014), por exemplo, por assegurar a reprodução natural da sociedade, com a centralidade do casamento heterossexual, a transmissão de um conjunto de valores e, por conseguinte, a libertação da nação em relação a pragas e catástrofes. Para defender sua presença pública, são feitos apelos recorrentes à liberdade de opinião e à liberdade religiosa (Giumbelli, 2014), as quais podem ser tomadas para análise como formas da gramática da cidadania democrática constitucional.

Mas, como pondera Montero (2013), embora o Estado republicano seja fundado na laicidade, sob o ponto de vista da percepção dos atores ela não significou uma adesão ao secularismo. Portanto, de um lado, junto à consagração constitucional da laicidade perdura um dissenso no que se refere à neutralidade da vida pública em relação à religião, e, de outro, atores políticos religiosos foram constrangidos a adquirir domínio sobre uma nova gramática para que suas ações pudessem ser percebidas socialmente como legítimas. O modo de atuação no espaço público prescrito pela Constituição constrangeria, por exemplo, os agentes religiosos a justificar suas posições de determinadas maneiras, a abrir mão de outras, e, fundamentalmente, a respeitar o contraditório, o que significa,

12 Ilustrativamente, em uma rápida busca com o uso dos descritores "bancada evangélica", "oração" e "Congresso" temos: Castro; Mattos, 2013; Dip, 2015; UOL, 2016.

13 Como esclarece Nadia Urbinati (2014, p. 39), "political body is held together by the fact that all the citizens agree on the ends of the political order, on the principles that allow those means to operate, and on the means by which the government and the deliberative processes operate (we might call this underlying agreement a constitutional ethos)". 
no mínimo, conviver com verdades alheias. Com isso, não só a religião se transfigura, de fato, em opinião na esfera pública, como também, a julgar pelas estratégias discursivas dos próprios atores, a gramática religiosa se tornaria menos densa do que a da cidadania e a dos direitos (Beyer, 2012).

De que modo poderíamos apreender esse religioso transfigurado em secular no debate público? O sociólogo argentino J. M. Vaggione (2011) opera com uma categoria analítica que nos parece útil para apreender e elucidar as estratégias da religião no debate público em uma democracia constitucional, em que, conforme temos argumentado neste artigo, a formulação do argumento em linguagem religiosa não é percebida como válida e em que ele deve, então, travestir-se de secular. Trata-se da categoria "secularismo estratégico" (Vaggione, 2011). Vaggione (2011) afirma que nos debates públicos em democracias constitucionais atores políticos religiosos instauram um tipo de "política bifronte". De um lado, buscam conservar seus privilégios como instituição religiosa; de outro, reclamam o direito de intervir no debate público como atores da sociedade civil (Vaggione, 2011). Reclamam, em outros termos, privilégios no que se refere à criação e manutenção de um espaço de produção e circulação de opiniões com status de verdade, e também igual liberdade de tomar parte no debate público em comparação com atores políticos que não desfrutam daqueles privilégios. Conforme Vaggione (2011), para que suas intervenções sejam percebidas como legítimas, as instituições religiosas aprendem a semântica da "cultura pública" do país, que no caso do Brasil, como apreendemos de Montero (2013), pode conter elementos religiosos, mas não pode se resumir a eles.

Em se tratando de direitos familiais, as instituições religiosas operariam, por exemplo, mutações em seu próprio discurso no intuito de adaptá-lo a outras gramáticas no espaço público para defender uma concepção tradicional de família. Nessa hipótese temos o que Vaggione (2011) chama de "uso estratégico do secularismo", compreendendo ações políticas que buscam aproveitar o compromisso democrático com a liberdade para a promoção de uma moralidade religiosa. Para isso, os atores tanto travestem essa moralidade de vestes seculares, quanto releem as normas jurídicas, em especial os direitos humanos, reclamando sua origem e inspiração cristã ${ }^{14}$. Esse uso estratégico do secularismo pode ser apreendido, por exemplo, quando se atenta para a presença de discursos biológicos e legais enunciados por instituições religiosas e grupos conservadores no debate sobre os mais distintos temas: no caso da adoção por casais do mesmo sexo, especula-se acerca dos danos psicológicos que

14 Sobre o assunto ver Moyn (2015). 
a falta de um homem ou de uma mulher pode causar à criança ${ }^{15}$, bem como se apela ao direito natural, que, argumentam, fundamentaria todo o sistema jurídico positivo ${ }^{16}$.

Pensando em termos de “imaginário evangélico" (Sant'Ana, 2014), podemos considerar o direito natural como uma forma gramatical que possibilita a atores religiosos o trânsito de uma normatividade religiosa ao ordenamento jurídico de democracias constitucionais, ou seja, uma normatividade laica, com potencial de reclamarem para o cristianismo e, por consequência, para as suas ideias e moralidades uma precedência em relação a ela. No direito natural, tal como modulado por esses atores, estariam inscritas prescrições concernentes aos usos do corpo, inclusive para a obtenção de prazer erótico, e o matrimônio deveria ser protegido pelo direito positivo em razão do propósito da procriação, que é de interesse público.

Essas prescrições, seus efeitos de regulação sobre os usos do corpo, têm sido atacadas por teóricos como Michael Warner, Judith Butler, Eve Sedgwick e, no Brasil, Richard Miskolci, entre outros. Há algumas décadas esses teóricos têm formulado sua crítica transitando entre a teoria literária, a teoria política, a sociologia e a antropologia. Embora seja mais comumente associada à teórica norte-americana Judith Butler, a categoria "heteronormatividade" foi cunhada por Michael Warner, que a consagra em sua introdução à coletânea Fear of a Queer Planet, de 1991. Em linhas gerais, a categoria aponta para uma crítica ao pressuposto da naturalidade da heterossexualidade, do qual decorreriam prescrições quanto ao sexo, ao gênero e ao desejo. Nas palavras do sociólogo Richard Miskolci (2009, p. 156),

[...] a heteronormatividade expressa as expectativas, as demandas e as obrigações sociais que derivam do pressuposto da heterossexualidade como natural e, portanto, fundamento da sociedade (notas internas omitidas). Muito mais do que o aperçu de que a heterossexualidade é compulsória, a heteronormatividade é um conjunto de prescrições que fundamenta

15 Em seu relatório, Fonseca argumenta que "ainda são feitos trabalhos científicos que apontam comportamentos ligados ao homossexualismo (sic) como relacionados a distúrbios, objeto de estudo na medicina. Como tais assuntos não estão cabalmente definidos pela academia científica, não se pode subordinar a direção da vida de crianças a potenciais riscos” (BRASIL, 2014, p. 20). Em um contencioso político em que os direitos, os bens, os recursos, o respeito e o apreço, bem como as palavras, as ideias, as categorias e as narrativas, são disputados, o uso da categoria 'homossexualismo' pelo deputado Ronaldo Fonseca evidencia a sua posição no debate acerca das demandas de pessoas LGBTT por direitos e, não menos importante, a ilegitimidade da sua não-heterossexualidade. Podemos apreender mais claramente a tonalidade e suas impressões a respeito quando consideramos que o termo "homossexualismo" tem conotação de patologia, sendo essa perspectiva repudiada tanto pelo movimento LGBTT, quanto por órgãos de classe, como o Conselho Federal de Psicologia (2017).

16 BRASIL. Câmara dos Deputados. Relatório substitutivo para a comissão especial destinada a proferir parecer do projeto de lei n 6.583, de 2013. Relator: Ronaldo Fonseca. Brasília: 2014. Nessa linha, lemos no relatório Fonseca, por exemplo, que, “apesar de o Estado ser laico, por não possuir religião oficial, nem influência de autoridades eclesiásticas no Estado, todo o arcabouço jurídico que o constituinte coloca, incluindo-se a dignidade da pessoa humana, a igualdade perante a lei e demais direitos fundamentais, individuais e coletivos, é dado sob a proteção de Deus” (BRASIL, 2014, p. 16). 
processos sociais de regulação e controle, até mesmo aqueles que não se relacionam com pessoas do sexo oposto.

O argumento de Butler (2010), sobre o qual Miskolci (2009) e outros elaboram, é que a naturalidade da heterossexualidade é socialmente construída, e a sua construção como tal tem amparo em meios materiais, que tornam a sua reificação uma possibilidade. Nessa linha, a naturalidade da heterossexualidade não é, portanto, apenas ideacional, mas também tem uma dimensão material. Tomada como padrão cultural socialmente compartilhado, a heteronormatividade, ou a naturalidade da heterossexualidade, tem efeitos sociais porque regula condutas mediante instituições formais, normas jurídicas, hierarquias sociais nela baseadas e afeta a distribuição de bens e recursos (Fraser, 1997; Butler, 2003). Seus efeitos materiais e simbólicos são especialmente sentidos em questões de família, que historicamente se constitui como um lugar de produção de normalidade, de transmissão da religião e uma instituição central em matéria sucessória e naquelas relacionadas com a seguridade social (Butler, 2003). Para Butler (2010) se trata de uma norma cultural que constitui o que ela chama, com Michel Foucault (1979), de matriz de inteligibilidade, entendida ela mesma como um conjunto estreitamente articulado de normas concernentes ao sexo (macho-fêmea, homem-mulher), ao gênero (femininomasculino) e ao desejo (heterossexual-homossexual) com base no qual as pessoas são mais ou menos inteligíveis como pessoas - como humanos -, conforme as suas performances, ou seja, os seus atos, as suas falas, os seus gestos, as suas aparições públicas evidenciem uma continuidade ou descontinuidade de sexo, gênero e desejo.

Descontinuidades costumam suscitar ansiedade no meio social, a qual estudiosos têm proposto alcançar pela categoria "pânico moral"17. No Brasil e alhures ${ }^{18}$ a relação entre homossexualidade, identidade de gênero e família tem sido propícia a acionar esse mecanismo. Em primeira análise, isso se dá porque convencionalmente se entende, como a Declaração Universal dos Direitos Humanos (1948), que "a família é o núcleo natural e fundamental da sociedade" (artigo 16), o que é lido como a apontar para a necessidade de

17 O historiador Jeffrey Weeks (2002) argumenta que esse mecanismo é particularmente devastador em questões sexuais, em função do lugar da homossexualidade nas convenções sociais - no caso dele - no mundo anglo-saxão. Butler (2003) e Miskolci (2007) identificarão o mesmo fenômeno em outros contextos locais. Segundo Weeks, com a AIDS esse mecanismo teria sido acionado, com efeitos inclusive dentro do que era a comunidade gay, e um pânico moral teria se instaurado na forma de cuidado da saúde. Weeks esclarece que "the mechanisms of a moral panic are well known: the definition of a threat in a particular event (a youthful 'riot', a sexual scandal); the stereotyping of the main characters in the mass media as particular species of monsters (the prostitute as 'fallen woman', the paedophile as 'child molester'); a spiralling escalation of the perceived threat, leading to the taking up of absolutist positions and the manning of the moral barricades; the emergence of an imaginary solution - in tougher laws, moral isolation, a symbolic court action; followed by the subsidence of the anxiety, with its victims left to endure the new proscriptions, social climate or legal penalties" (Weeks, 2002, p. 45).

18 Weeks (2002) o abordou considerando o mundo anglo-saxão e Nagamine (2017) olhando para Uganda. 
se preservar a possibilidade de reprodução natural dentro da família. Então, a possibilidade de reprodução natural torna-se um critério determinante do que é uma família legítima e legal. Em segunda análise, tais reações de ansiedade remetem ao argumento butleriano segundo o qual a inteligibilidade da pessoa passa por sua adequação às normas culturais do binarismo sexual, de gênero e desejo, que estariam condensadas na família, tomada como lugar de produção e criação de seres humanos. Em termos empíricos, enfim, elas resultam em uma produção discursiva abundante de atores que acabam por configurar um contencioso político (Tarrow, 2009), uma disputa sustentada no tempo em que eles usam estratégias e enquadramentos para superar constrangimentos e explorar oportunidades.

$\mathrm{Na}$ seção seguinte recuperamos e analisamos as produções discursivas de outros deputados federais brasileiros em defesa do Estatuto da Família. Suas falas evidenciam, aos nossos olhos, como a religião se traveste de argumentos biológicos e jurídicos para, segundo o nosso argumento, assegurar um lugar legítimo para si no debate público sobre direitos no Brasil.

\section{A participação de parlamentares cristãos no Estatuto da Família}

Embora haja outro projeto de lei em discussão no Senado Federal (BRASIL, 2013b), com a proposta concorrente de ampliar a noção de entidade familiar de modo a abranger as famílias formadas por casais de pessoas do mesmo sexo, é o Estatuto da Família que tem atraído maior atenção e suscitado reações mais estridentes, de apoio e de rejeição. O projeto parece ter se constituído, assim, em objeto de uma controvérsia pública (Montero, 2012).

Reconstruindo as disputas mais recentes acerca das relações conjugais entre pessoas do mesmo sexo, podemos tomar o Estatuto da Família como uma reação a dois momentos cruciais do processo de afirmação formal das demandas de gays e lésbicas por direitos familiais no Brasil: a regulação da união estável em abstrato pelo Supremo Tribunal Federal, em maio de 2011, e a instituição do casamento pelo Conselho Nacional de Justiça, em maio de 2013 (Barbosa; Nagamine; Natividade, 2016). De uma perspectiva sócio-jurídica, interessa-nos, entretanto, que o Estatuto da Família tem sido calorosamente defendido por parlamentares da Frente Parlamentar Evangélica, não menos duramente combatido por defensores dos direitos de pessoas LGBTT na Câmara dos Deputados, e sua propositura tem suscitado um acalorado debate extrainstitucional.

Os que reclamam direitos de homoconjugalidade e seus representantes no Legislativo federal formulam suas demandas em termos de igualdade entre as relações homo e heteroconjugais e as enquadram como uma questão de direitos humanos e de cidadania. Eles argumentam, nessa linha, que a família deve ser concebida como uma instituição social cuja proteção jurídica deve ser atualizada à luz de suas transformações históricas. Também interpelam o compromisso de deputados que apoiam o projeto de lei com instituições e grupos religiosos, a assinalar que a ação política informada puramente por ideias e moralidade religiosas é ou pode ser percebida socialmente como ilegítima. Para 
eles, a inspiração religiosa de certas proposições é um atentado contra a neutralidade do Estado em relação aos seus cidadãos e os diferentes projetos de vida deles. Essa visão aparece, por exemplo, na fala da deputada Erika Kokay (PT/DF) (BRASIL, 2015a), que entende que os deputados "podem defender qualquer coisa, mas não podem romper a laicidade do Estado" (BRASIL, 2015a). Segundo Kokay (BRASIL, 2015a), em um Estado de Direito não se pode aceitar que deputados eleitos democraticamente transformem seu mandato em uma defesa de concepções religiosas, porque essa atitude "feriria um princípio fundamental segundo o qual o Estado é de todos”. Esse tipo de argumentação encontra ressonância fora e dentro do Congresso Nacional, entre deputados que se posicionam a favor de direitos de gays e lésbicas, como Glauber Braga (PSOL/RJ), para o qual

Da mesma forma que eu não posso considerar natural e razoável um processo de discriminação estatal a qualquer religião para se estabelecer o monopólio de uma religião, porque o Estado tem que ser laico, eu não posso também querer estabelecer através de uma ação estatal um modelo único de família. Também nesse caso está havendo uma interferência inadequada, que também é brutal por parte do Estado nessa definição. (BRASIL, 2015a).

O deputado subentende que o fundamento da não discriminação de gays e lésbicas é o mesmo da não discriminação por religião, ou seja, do que instituições e líderes entendem por liberdade religiosa no Brasil. Podemos entender que se trata, no limite, de um compromisso com uma moralidade não hegemônica, isto é, nos termos do deputado, com o não ‘monopólio’ da religião no que se refere a prescrições morais inscritas em lei e a rejeição a um 'modelo único' de família. Já Kokay assinala que as religiões são iguais perante o Estado, mas não prescrevem um modelo de família a ser protegido pelo direito. Nessa linha de argumentação, podemos entender que crenças religiosas e seculares (Taylor, 2010; Hurd, 2015) deveriam ser equiparadas para fins de proteção estatal, de modo que a laicidade prescreveria, ao mesmo tempo, a igualdade entre religiões e a igualdade entre crenças e práticas religiosas e seculares. Ela asseguraria, em outras palavras, um lugar ao não religioso, laico ou secular na esfera pública brasileira, isto é, em uma esfera que, segundo Montero (2006, 2012, 2013) e Giumbelli (2014), seria culturalmente atravessada por valores, ideias e ideais cristãos.

Mas, como dissemos, a laicidade é um objeto de disputa no Congresso Nacional. Na primeira Comissão Especial destinada a proferir parecer ao PL 6.583/2013, formada em 2014, dezessete dos seus vinte e dois membros titulares eram parte ou da Frente Parlamentar Católica ou da Frente Parlamentar Evangélica. Essa composição, em que predominam parlamentares ligados a bancadas religiosas, replicou-se na Comissão Especial de 2015. Nela, vinte dos seus vinte e sete titulares faziam parte de uma ou de outra frente. Em ambas, a oposição ao projeto, sempre minoritária, foi efetuada quase unicamente por partidos de esquerda, com destaque para PSOL, PCdoB e PT. Há membros da Frente Parlamentar Evangélica e da Frente Parlamentar Católica que são filiados a partidos de esquerda. No entanto, nenhum membro das Comissões Especiais filiados a esses partidos figura entre os seus membros titulares. Em contrapartida, deputados que votaram contra o 
Estatuto, como João Carlos Bacelar (PTN/BA) e Maria do Rosário (PT/RS), definemse como católicos praticantes, mas sua filiação religiosa não influencia a sua postura no debate público sobre esses direitos especificamente. Já a inspiração cristã, ou filiação religiosa, é reclamada pelos próprios deputados que apoiam o Estatuto da Família. Nos debates nas Comissões Especiais, eles habitualmente se apresentam como defensores de valores cristãos, argumentando, como o deputado Givaldo Carimbão (PHS/AL), que

A democracia é isso:tem gente que defende uma tese e outros que defendem outra, e o Parlamento é que vai decidir. Eu fui eleito assumidamente pela Igreja Católica Apostólica Romana, eu tenho uma irmã freira e três tios padres, toda uma história católica. Eu vim aqui em nome de um movimento, como o Jean Wyllys veio em nome de outro movimento. Normal e legítimo. A Bíblia para mim está em primeiro lugar do que a Constituição. Tem a lei de Deus e a lei dos homens, eu não posso ferir a lei de Deus com a lei dos homens. No palanque eu sou contra o aborto, sou contra o casamento homossexual. Pode ter certeza que quem é a favor não vota em mim. (BRASIL, 2015b)

Nessa fala, (i) a religião aparece como movimento social, (ii) as crenças religiosas e seculares são equiparadas umas às outras, (iii) para ele, como deputado, orientar-se pela Constituição Federal ou pela Bíblia, pelo ethos constitucional ou por suas crenças religiosas, é uma questão de preferência, logo, de liberdade e (iv) a 'lei de Deus' se sobrepõe à 'lei dos homens'. Embora a democracia representativa se caracterize pelo mandato político não vinculado, o deputado parece ter recebido um mandato imperativo quando afirma estar no Congresso 'em nome de um movimento', ao menos no que se refere ao aborto e 'casamento homossexual', em relação aos quais ele é contra e 'pode ter certeza que quem é a favor não vota em mim'. Por fim, podemos notar, em sua fala, uma articulação particular, embora recorrente em instituições e congregações cristãs, entre lei dos homens e lei de Deus, com uma inversão em relação à hierarquia das normas em uma democracia constitucional, que prescreve a precedência das normas constitucionais a quaisquer outras no trato dos assuntos de interesse geral.

Em linha com esse entendimento, para as instituições religiosas de um modo geral e os parlamentares que se definem como deputados cristãos em particular, sua intervenção na esfera política decorre do direito de cada um defender a sua verdade, em oposição a ações que ameaçam os valores cultivados por eles e suas instituições de origem (Gomes; Menezes; Natividade, 2009). Trata-se, em síntese, de uma opinião como outra qualquer e que se deve ter a liberdade de defender. Como podemos notar, a democracia aparece, aqui, em estreita ligação com a liberdade de associação e a participação popular. Por força dessas liberdades, seria legítimo que instituições e grupos religiosos elegessem candidatos comprometidos com a defesa de seus valores e suas visões de mundo no Congresso Nacional. O argumento, aqui, é que, eleitos, esses parlamentares estariam livres para elaborar leis em consonância com a vontade da maioria, pois que teriam passado por um duplo crivo democrático. 
Mas a democracia também reaparecerá na produção discursiva de nossos atores religiosos como sinônimo da vontade da maioria. Eles ponderarão que a maioria dos brasileiros se declara cristã e disso concluirão que a população é majoritariamente contrária ao casamento de gays e lésbicas, porque seus relacionamentos seriam pecaminosos. $\mathrm{O}$ relator da Comissão Especial de 2014, deputado Ronaldo Fonseca (PROS/DF), afirma, por exemplo, que a laicidade do Estado deve ser relativizada ou afastada quando contraria a vontade da maioria. Para ele,

Apesar de o Estado ser laico, por não possuir religião oficial, nem influência de autoridades eclesiásticas no Estado, todo o arcabouço jurídico que o constituinte coloca, incluindo-se a dignidade da pessoa humana, a igualdade perante a lei e demais direitos fundamentais, individuais e coletivos, é dado sob a proteção de Deus. Nesse sentido, deve-se também esperar respeito desta Casa ao credo reconhecidamente balizador dos valores da maioria absoluta de religiosos e não religiosos e que construiu nossa sociedade brasileira, bem como todo o Ocidente. Isso, indiscutivelmente, faz trazer como família admissível a iniciada com um homem e uma mulher. Não é à toa a preocupação de colocá-la de maneira literal na CF (art. 226, \$3º, para não haver dúvidas). Ademais, não se pode considerar que a família seja invenção da religião, mas ela é reconhecida na religião como algo essencial à sociedade e merecedora de respeito por parte do Estado, que não deve querer modificá-la, apenas pode ver motivos para protegê-la. Não se trata, portanto, de uma questão religiosa, mas de respeito à opinião da população, que, além de ver razões fáticas que fazem da família uma instituição merecedora de proteção e normatização, a consideram o centro do ensino, desenvolvimento e orientação do indivíduo sob a proteção de Deus. (BRASIL, 2014)

Sem apelar manifestamente ao direito natural, Ronaldo Fonseca ecoa aqueles que reclamam a fundação cristã dos direitos humanos e, com base nela, postulam que sua leitura seja informada por princípios bíblicos, ou, como encontramos em sua fala, não lhes seja contrária. Trata-se de um argumento recorrente nesse lado do debate acerca das demandas de gays e lésbicas por direitos familiais no Brasil. Sua argumentação parece oscilar entre o entendimento de que as proibições e as prescrições bíblicas são um critério de legitimidade das interpretações da Constituição Federal e aquele segundo o qual não se trata de uma questão religiosa, mas da visão que a maioria tem da família e de sua importância para a sociedade.

No que se refere à legitimidade da participação de políticos religiosos em atividades legislativas, ela também foi defendida na Comissão Especial pelo polêmico pastor Silas Malafaia, para o qual o princípio da laicidade não é aplicável ao Parlamento. Em linha com Ronaldo Fonseca, Malafaia afirma:

Deixa eu explicar uma coisa pra vocês: Estado laico é o governo. O governo é laico. Agora, eu gostaria de falar que o Parlamento não é laico e eu explico o porquê. Porque o Parlamento representa o povo. O Michael Sandel, um filósofo moderno de Harvard, diz o seguinte: "nenhum debate político pode descartar as crenças e valores de uma pessoa independente se o viés 
é ideológico ou religioso". Aí, eu digo uma coisa: a escola pública vem de onde? Reforma protestante. Direitos humanos e proteção à vida vieram de onde? O modelo judaico-cristão. A sociedade ocidental é permeada em seus costumes pelo modelo judaico-cristão. Em uma sociedade livre, o cidadão tem o direito de expor posições políticas baseadas em qualquer princípio, se são ateístas ou não. Por acaso Marx vale mais do que Jesus? (BRASIL, 2015b).

Nessa construção, Malafaia aposta no argumento de que as opiniões de atores religiosos são opiniões como outras quaisquer e devem poder circular livremente em uma democracia. Como assinala Giumbelli (2014), as liberdades e os espaços democráticos são usados em prol da livre circulação de ideias religiosas, que os atores duplicam, estrategicamente, como ideias seculares mediante sua formulação com gramáticas não religiosas na arena pública. Citando Michael Sandel, filósofo norte-americano que se tornou célebre no Brasil, Malafaia equipara, para esses fins, as ideias religiosas a ideologias seculares, que são consideradas legítimas participantes no debate público, como as de esquerda, encarnadas na figura de Marx, e as ateístas, que não raro se confundem com elas.

Em consonância com Malafaia, o relator da Comissão Especial de 2015, deputado Diego Garcia (PHS/PR) (Brasil,2015c),também busca legitimar a participação de religiosos na atividade legislativa ecoando o argumento da razão pública do teólogo de formação e teórico político de ofício John Rawls. Para Diego Garcia, o pertencimento religioso não define a índole do argumento lançado no debate público, nem torna legítimo reputar um político religioso de 'fundamentalista'. Recorrendo a ideias e categorias de Rawls, o deputado argumenta que, a despeito do seu 'fundamento íntimo', um ator político religioso pode efetuar um bem-sucedido esforço de tradução de uma ação inspirada na religião no que o norte-americano chamou de 'razão pública'. Nessa linha, Garcia aponta a dificuldade de se distinguirem argumentos religiosos e laicos, um desafio, de fato, quando se discute o tema da religião na esfera pública. (Brasil, 2015c).

Como outros, Diego Garcia também usa a ideia de 'laicidade' para diferenciála de 'laicismo', ou diferenciar o que podemos tomar por a laicidade como princípio ordenador das relações entre religiões, e a laicidade como dogma, um tema comum nas falas de atores políticos religiosos. Diferentemente de Malafaia, que apelou à liberdade de opinião, ele apela, então, para a liberdade religiosa contra o laicismo, chegando a afirmar que políticos religiosos seriam vítimas de 'perseguição', uma 'postura antidemocrática' e de 'intolerância religiosa'. Com esse enquadramento, responde à estratégia dos defensores das demandas de gays e lésbicas por direitos familiais de enquadrá-los como vítimas de intolerância religiosa, sendo "intolerância religiosa" entendida aqui, muito distintamente do sentido que ele lhe empresta, como uma depreciação operada por atores religiosos e ou informada por ideias religiosas.

Com base nessas falas, um traço comum aos discursos de políticos religiosos parece ser a distinção entre laicidade e laicismo, ou entre o que propomos denominar laicidade como princípio e laicidade como dogma. Também podemos perceber que a Constituição Federal aparece como um texto sagrado nas falas dos deputados federais pró-demandas 
de gays e lésbicas, e como normativa subposta à normatividade religiosa, à normativa cristã, nas falas de atores contrários a elas. Em compensação, em ambas concorrem ideias de religião pública e privada, da prevalência de direitos da maioria ou de minorias, da democracia como primordialmente vontade da maioria ou proteção de direitos humanos fundamentais, da separação dos Poderes republicanos como implicando, sobretudo, a abstenção de uns em relação aos outros ou o concurso entre eles.

Principalmente, tais falas assinalam que laicidade, família e sujeito de direitos são objetos de disputa em um processo em que a gramática jurídica é agenciada e o humano dos direitos humanos reconfigurado. Nelas podemos notar, enfim, as disputas no espaço público e as diferentes estratégias para sustentar, restringir ou ampliar a presença do religioso. No que nos interessa mais diretamente, nessas disputas teríamos, de um lado, uma crítica do uso ideológico da religião ou do uso dogmático da Bíblia e, de outro, uma crítica do uso ideológico da laicidade ou de um uso dogmático de certos preceitos constitucionais no debate público sobre afirmação de direitos.

Na seção seguinte, abordaremos o problema normativamente, pensando a legitimidade da participação de religiosos no debate público sobre direitos no Brasil, a partir de uma concepção alternativa de democracia, que Urbinati (2014) denominou "diárquica". Concebida desse modo, a democracia representativa é composta de dois elementos, decisão e deliberação, isto é, voto e opinião. A abordagem teórica de Urbinati (2014) enfoca a deliberação, supondo que, em uma democracia constitucional, as opiniões dos cidadãos precisam circular para informar a decisão e manter o jogo democrático, o qual dependeria da consistência das relações entre instituições e opinião pública. Segundo Urbinati, a formação e circulação de opiniões se dariam em um processo de competição aberta que requer distintos tipos de liberdades e o direito de influenciar o sistema indiretamente, dado que se trata de um "processo orientado para a lei" (Urbinati, 2014, p. 6). Mas, traduzida em leis que limitam a autonomia de setores não religiosos da sociedade, a presença de religiosos no espaço público pode colocar em risco o pluralismo e a laicidade do Estado? Como equilibrar o direito de associação e a participação democrática de grupos religiosos em um Estado democrático e, ao mesmo tempo, garantir a laicidade e o pluralismo?

\section{Lei civil, lei religiosa e a instrumentalização da laicidade}

Pensando a partir da controvérsia sobre símbolos religiosos no espaço público italiano, Urbinati tem por pressuposto que, em uma democracia constitucional, a ação pública do religioso assume um estilo deliberativo, isto é, de respeito ao contraditório e argumentação articulada na linguagem dos direitos (Marzano; Urbinati, 2013). A possibilidade de operar uma espécie de transfiguração do religioso em secular teria sido dada por transformações de ordem constitucional, como são, em nosso entender, a proteção irrestrita à liberdade de opinião, a não interferência do Estado na religião e a igualdade dos direitos humanos uns com os outros. Para Marzano e Urbinati (2013), essas transformações teriam aberto o 
espaço público a novos modos de ação de religiosos, colocando desafios importantes para a democracia constitucional.

O problema de que nos ocupamos nos possibilita formular alguns desses desafios. Ele se configura a partir da eleição de políticos declaradamente cristãos que, uma vez na Câmara, agem para que a elaboração de leis e a leitura de direitos já consagrados sejam informadas por preceitos cristãos. Sendo o Brasil uma democracia constitucional, seria preciso e desejável estabelecer quais plataformas são legítimas ou quais são ilegítimas a se sustentar politicamente? Seria pertinente proibir ou coibir uma parcela religiosa da população de participar das deliberações mesmo que usando uma linguagem secular? Pedir que cidadãos e políticos profissionais religiosos façam uma tradução de argumentos religiosos para uma linguagem secular viola a igualdade entre os cidadãos, como argumenta Habermas (2003)? Por fim, a tradução de preceitos religiosos em argumentos seculares no processo de deliberação é suficiente para que a laicidade do Estado não seja violada?

Urbinati parte da crítica de Habermas a Rawls para pensar o lugar do religioso nas democracias constitucionais (Marzano; Urbinati, 2013; Urbinati, 2010). Supondo que o elemento fundamental das democracias representativas consiste na circulação de opiniões entre sociedade e instituições, Urbinati pondera que as posições de ambos os teóricos, a de Habermas mais pós-secularista que a de Rawls, têm como pano de fundo sociedades liberais em que há pluralismo religioso tanto de fato quanto de direito (Marzano; Urbinati, 2013; Urbinati, 2010). Por isso, os argumentos e critérios fornecidos por eles não se prestariam bem a serem aplicados a sociedades democráticas em que uma confissão religiosa conta com uma forte maioria e o pluralismo não é um dado da vida social. Com base nesse argumento, Urbinati sustenta que, para pensarmos o lugar da religião em democracias constitucionais, é preciso distinguir entre sociedades em que o pluralismo religioso é um fato e um direito, daquelas em que o pluralismo religioso é protegido por lei, mas não constitui uma realidade social, nem um ethos a inspirar o raciocínio público dos cidadãos comuns (Marzano; Urbinati, 2013; Urbinati, 2010).

Podemos entender que, na abordagem de Urbinati (2010), o pluralismo é, assim, um critério normativo para se analisar o papel das religiões em democracias constitucionais. Tendo o pluralismo por critério, Urbinati pondera, contrariamente à crença pós-secular na autorregulação do mercado de ideias, que o caráter público de uma deliberação não reside apenas no estilo e nos princípios que a informam, mas também em seus objetivos, os quais ela resume na tomada de decisões a serem aplicadas a todos (Marzano; Urbinati, 2013; Urbinati, 2010). Urbinati entende que apenas se assumirmos "uma perspectiva orientada para a lei", isto é, que entenda que a deliberação resulta em leis gerais e abstratas, poderemos compreender e julgar adequadamente o papel e o lugar da religião no espaço público (Marzano; Urbinati, 2013; Urbinati, 2010).

Para discuti-los, propõe-se proceder analiticamente a partir do par leis civis-leis religiosas. Concebendo a democracia como um processo de formação e circulação de opinião cujo fim é a tomada de decisão, Urbinati pondera que o fato de religiosos criticarem determinadas leis e proporem outras quando entram no espaço público justifica 
reforçar o papel da decisão, em especial relacionada com a lei civil, que é, para ela, a forma que a decisão assume nos Estados constitucionais modernos (Marzano; Urbinati, 2013). Pensando nesses termos, Urbinati (2010) argumenta que a dissociação da legitimidade do Estado em relação à religião significou, por um lado, que o Estado renunciou a manifestar sua preferência por uma ou outra confissão e, por outro, que as religiões renunciaram a reclamar prerrogativas relacionadas com a lei civil. Isso não significa que não haja disputas acerca de religião nem que instituições religiosas não entrem em disputa acerca de questões da cidadania: significa, simplesmente, que, em uma sociedade democrática, a tensão entre religião e secularismo não é reprimida. Nela, não se elege um critério para dar a essa tensão uma solução definitiva, nem se constitui um dogma, um valor inquestionável e unívoco que possa ser usado para equacioná-la. Pelo contrário, é, em parte, o fato de essa tensão se recolocar constantemente na esfera pública que torna uma sociedade, ao mesmo tempo, democrática e secular (Marzano; Urbinati, 2013), uma sociedade em que o processo de elaboração de leis resulta da constante comunicação entre domínios institucionais e extrainstitucionais.

Urbinati (2010) parece estar, nesse ponto, de acordo com Habermas. Em marcada diferença entende, porém, que Habermas pretende incorporar a religião plenamente na esfera da deliberação, tratá-la como uma gramática plenamente legítima no espaço público, tendo por pressuposto que uma discussão aberta lograria transformar diferenças doutrinárias ou dogmáticas em diferenças de interpretação, a serem julgadas pela razão pública. $\mathrm{Na}$ opinião de Urbinati (2010), a pluralidade religiosa de facto contribui, contudo, para obstar o domínio das maiorias sobre as minorias e a sua transformação em norma. A autora não esclarece como isso se daria, mas podemos entender, seguindo sua linha de argumentação, que a pluralidade de fato recoloca constantemente a tensão entre religioso e secular, ou seja, torna mais difícil que uma ideia ou valor se consolide como critério a solucioná-la definitivamente. Sua crítica é informada, enfim, pelo entendimento de que o argumento habermasiano foi formulado com base em uma circunstância histórica de superação da necessidade do secularismo como princípio normativo ${ }^{19}$, a qual não se replicou em outras sociedades. Como dissemos antes, o argumento de Urbinati contra a tese pós-secularista, isto é, contra a crença em uma espécie de livre mercado das ideias, consiste em que ela é desfavorável à liberdade individual no que a autora chama de "sociedades monorreligiosas", como a Itália (Marzano; Urbinati, 2013) e, propomos aqui, também o Brasil.

Nessas sociedades, por mais que as igrejas se declarem respeitosas do secular, suas crenças, ideias, valores, práticas e símbolos podem se imiscuir no espaço público como cultura. Esse é o argumento de Montero (2012) e Giumbelli (2014) em relação ao catolicismo e a religiões africanas no Brasil, que procuramos apresentar em seção anterior, e também o de instituições judiciais internacionais, como a Corte Interamericana e a

19 Na leitura de Urbinati, a posição de Habermas tem por suposto que, nas sociedades ocidentais, as religiões passaram a aceitar o Estado Constitucional Liberal e, por isso, o público pode se permitir ser menos receoso da sua presença. Essa proposição tem por suposto que a lei civil venceu a guerra contra as igrejas, o que, para Urbinati, é uma suposição altamente contextual (Marzano; Urbinati, 2013). 
Corte Europeia de Direitos Humanos, em casos célebres como A última tentação de Cristo e Crucifixos na escola. Reformulando o problema, temos que, em sociedades monorreligiosas, a revisão do liberalismo proposta pelo pós-secularismo habermasiano ofereceria riscos para a democracia representativa.

Primeiro, considerando que o religioso também está presente como cultura nessas sociedades, é preciso cogitar que as arenas públicas sejam mais responsivas ao uso de gramáticas religiosas do que ao uso de gramáticas seculares, como, nas democracias constitucionais, tendem a ser a gramática jurídica e a da cidadania. De que modo a mudança social pacífica pode ter lugar em uma configuração desse tipo? Segundo, é a densidade e a onipresença do discurso público que, em uma democracia constitucional, constrangem os cidadãos a não usarem o espaço público como um meio para cumprir ou patrocinar a transformação das suas próprias crenças, ideias e ética em leis gerais. Para Urbinati, a questão é, portanto, que ideias religiosas também circulam entre os cidadãos e políticos profissionais, possibilitando a instituições religiosas formar grupos de pressão e eleger seus representantes para operar uma tradução de preceitos religiosos em leis civis, de modo a conformar o direito nacional ao seu código de condutas (Marzano; Urbinati, 2013; Urbinati, 2010). O argumento de Urbinati consiste em que, em sociedades democráticas, nas quais não há pluralidade religiosa de fato, mas há pluralidade de direito, ou liberdade religiosa, é preciso mais ethos constitucional e, para tanto, maior compromisso das instituições com a laicidade, que ela define como

A atitude da autoridade civil em relação às práticas religiosas que tem o objetivo de torná-las capazes de conviver pacificamente com práticas de natureza não religiosa e de outras religiões. É um modo de organizar a coexistência das liberdades. O escopo da laicidade é, antes de tudo, a paz social e a segurança das pessoas, a certeza de que a diversidade não será razão de intolerância, discriminação ou violência (Marzano; Urbinati, 2013, posição 1037 , tradução nossa ${ }^{20}$.

Podemos pensar, indo além de Urbinati, que o ethos constitucional teria, assim, compromisso fundamental com a pluralidade de facto e reafirmaria o pluralismo como princípio sempre que ela for ameaçada, sendo reforçado especialmente pela atuação do Judiciário. Em uma democracia constitucional, o modo de atuação do Judiciário seria adequado a esse fim por ele decidir os problemas caso a caso, ou seja, não se propor nem poder solucionar definitivamente as tensões entre o religioso e o secular ou o laico. Sua atuação compreenderia as relações entre crenças religiosas e liberdades seculares, mas também aquelas entre crenças seculares e liberdade religiosa. Em contrapartida, o reforço do ethos constitucional não implicaria a retirada da religião do espaço público e, por conseguinte, do debate democrático. Concebida naqueles termos, a laicidade, afinal, não se confunde com o 'laicismo' e o 'secularismo', os quais são projetos ideológicos de promoção do valor do Estado sobre todos os outros valores: teologias políticas que,

20 Trecho retirado da versão e-book do livro no Kindle. Neste aplicativo, as páginas são referenciadas como posição e não como página. 
precisamente por seu caráter doutrinário, violam o pluralismo e a própria laicidade (Marzano; Urbinati, 2013). Bem ao contrário, o desafio que se apresenta a democracias constitucionais sem pluralidade religiosa de fato consiste em assegurar que a diferença não implique nem justifique uma desigualdade, sem que esse esforço resulte na retirada da religião do espaço público. $O$ instrumento de que elas dispõem para tanto é, no atual arranjo democrático constitucional, a elaboração de leis destituídas de conteúdo doutrinário específico, independentemente de o seu conteúdo ser ou não compartilhado pela maioria da população. Para Urbinati, a laicidade de uma lei é, em síntese, a medida de sua generalidade, o sinal da sua capacidade de incluir todos, isto é, os poucos e mesmo os muito poucos que têm crenças diferentes (Marzano; Urbinati, 2013).

\section{Considerações finais}

No debate sobre o Estatuto da Família, políticos religiosos ${ }^{21}$ procuram justificar a sua posição argumentando que falam pela maioria da sociedade brasileira. Com base no que temos discutido aqui, esse argumento se mostra problemático em mais de um aspecto. Ele está baseado no pressuposto de que a adesão manifesta ou tácita da maioria é o critério determinante da legitimidade e da legalidade na democracia, independentemente da matéria. Depois, supõe que a maioria da sociedade, por declarar que professa a mesma fé, também interpreta do mesmo modo os preceitos religiosos e que a "religião das instituições" se confunde com a "religião das congregações"22 (Marzano; Urbinati, 2013) ou que aquela se impõe a esta.

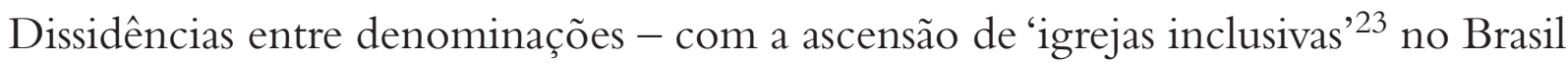
e a mudança de posicionamento de denominações, como a Igreja Anglicana em todo o mundo, ou dentro de 'igrejas tradicionais' ${ }^{24}$, com a emergência de vozes dissonantes na Igreja Católica, e entre igrejas pentecostais - desafiam esse suposto, aparecendo como um sinal claro de que outras interpretações podem ter maior lugar no debate público. Julgando por manifestações de grupos evangélicos na Parada do Orgulho Gay de São Paulo de 2015 (BALLOUSSIER, 2015) e de 2017 (MORETTI, 2017), com as mensagens "Jesus cura a homofobia", "Desculpem-nos pelo modo como a igreja trata vocês" e "Evangélicos pelos direitos da comunidade LGBT", essas interpretações, por ora minoritárias no campo religioso, podem encontrar apoio nas congregações.

Com base nas falas recuperadas dos debates acerca do projeto de lei nas Comissões Especiais da Câmara dos Deputados, a maioria que os deputados religiosos reclamam representar de fato seria precária, isto é, formada em relação a questões específicas. É em

21 No caso destes, especialmente os ligados à Renovação Carismática.

22 As categorias são de Marzano e assinalam uma disjunção importante o suficiente para justificar a análise do fenômeno religioso em dois níveis distintos.

23 Ver nota 4.

24 Ver nota 5. 
nome dessa maioria que políticos cristãos conservadores têm buscado justificar suas ações destinadas a retirar direitos familiais de gays e lésbicas afirmados pelo Supremo Tribunal Federal e pelo Conselho Nacional de Justiça. Mas, não obstante as suas alegadas fragilidades em debates como esse, o argumento da representação da maioria tem ressonância porque uma ideia forte de democracia é a da prevalência do maior número. Em uma democracia constitucional, como o Brasil, o lugar das minorias costuma ser discutido como uma questão de direitos humanos fundamentais. Tem-se entendido que, nela, esses direitos podem ser adquiridos gradualmente, em processos políticos, com ou sem a atuação das cortes nacionais. Elaborando sobre a rica literatura sociológica dedicada ao estudo do direito nos chamados novos movimentos sociais (McCann, 2006), podemos considerar que essas cortes tendem a ser acionadas quando os constrangimentos sociais ao avanço de determinada agenda no Legislativo são grandes, mas o apoio a esse avanço é suficiente para que o Judiciário, uma vez acionado, possa conceder a demanda sem comprometer sua autoridade: conforme o caso, o poder de barganha do Judiciário nacional pode ser ampliado por decisões de instituições internacionais, como a Corte Interamericana de Direitos Humanos (Nagamine, 2017). Também por isso podemos pensar que a representação da maioria possibilita a atores religiosos justificar outra reclamação comum, a da ilegitimidade do Supremo Tribunal Federal para "legislar" sobre o assunto, isto é, para proferir decisões gerais.

Curiosamente, esse argumento de atores religiosos encontra eco entre renomados constitucionalistas brasileiros $^{25}$, que reconhecem a justiça da demanda de gays e lésbicas, mas consideram que, no caso das uniões estáveis entre pessoas do mesmo sexo, as "uniões homoafetivas", o Supremo Tribunal Federal comprometeu a separação de poderes ao proferir decisão em abstrato sobre tema nunca deliberado pelo Legislativo federal. Não se tem aqui, portanto, um uso propriamente estratégico da democracia, mas uma espécie de reforço de um princípio do ethos democrático, a separação de poderes. Esse argumento específico tem sido rechaçado, no entanto, com apelos a uma alegada função contramajoritária das cortes no geral e do Supremo em particular, ou seja, com um deslocamento do acento democrático da soberania e a separação de poderes para os direitos individuais (Urbinati, 2014).

De fato, a formação de maiorias é um elemento democrático importante, mas a ideia de democracia, como Urbinati (2010) mostra e diferentes atores políticos acentuam, é mais ampla e densa do que a de maioria, compreendendo outros elementos além da sua formação e manifestação. Contra a argumentação centrada na maioria, defensores dos direitos familiais de gays e lésbicas, aí incluídos atores religiosos, como as igrejas inclusivas', apelam aos direitos humanos, à igualdade e à laicidade, esta entendida como a separação entre Estado e religião. Porém, a associação de religiosos para a formação de partidos políticos é permitida e não se proíbe que fiéis de uma religião escolham um de seus membros para representá-los no Legislativo. Mesmo a formação de partidos políticos de inspiração religiosa não colocaria, necessariamente, um desafio ao Estado laico, o que 
só ocorreria se aqueles políticos e seus eleitores formulassem seus argumentos no espaço público usando a linguagem da religião.

No debate acerca do Estatuto da Família, percebemos que atores políticos cristãos conservadores buscam efetuar essa tradução. Uma dificuldade a esse respeito é justamente que os que falaram nas Comissões Especiais em defesa do projeto de lei apelaram basicamente a argumentos seculares. Com Urbinati (2010), podemos contemplar, nesse caso, uma espécie de instrumentalização de espaços laicos, isto é, espaços ligados à pluralidade, formal ou factual, para ampliar a presença religiosa na esfera pública, com efeitos sobre minorias - o que a autora designou de "laicidade ao avesso".

Essa instrumentalização da laicidade e o consequente uso de argumentos seculares por atores políticos religiosos para ampliar o espaço da religião têm potencial para tornar posições e argumentos religiosos mais ressoantes em democracias constitucionais e mais dificeis de capturar sem afrontar a liberdade religiosa e de opinião. Em um esforço por apreender essa forma de atuação,Vaggione (2005) fala em "secularização estratégica”, segundo a qual atores políticos religiosos lançariam mão de argumentos aos quais não aderiram realmente, mas que reconhecem oferecer um ganho importante no debate público em um Estado laico. Já com Urbinati (2010) podemos operar com o par lei civil-lei religiosa. Para ela, a separação entre ambas seria um traço distintivo da democracia constitucional e do Estado laico, partindo do pressuposto de que não há democracia constitucional sem laicidade. De uma perspectiva normativa, a instrumentalização da laicidade não torna, por isso, argumentos destinados a confundir leis civis e leis religiosas que sejam formulados em linguagem secular mais justificados em uma democracia constitucional.

Com base na seção anterior, podemos considerar que um argumento principal dessa ordem em defesa do Estatuto da Família é a literalidade da Constituição Federal, que fala em "homem" e "mulher" quando consagra a união estável. Outro, que pode ser apreendido nas entrelinhas das falas dos deputados religiosos e especialistas, seria o lugar sagrado da Constituição na ordem democrática e sua consequente imutabilidade, enquanto defensores dos direitos de gays e lésbicas apostariam em enquadrá-los como direitos humanos e de cidadania, usados como uma espécie de legalidade superior, a que os legisladores estariam constrangidos a adequar sua leitura da Constituição. Os dois argumentos de atores religiosos se desdobrariam (i) em uma defesa da interpretação histórica ou gramatical do texto constitucional, privilegiando a vontade do legislador e a literalidade da lei em detrimento de interpretações teleológicas, (ii) bem como na incompetência do Supremo Tribunal Federal para 'legislar' sobre o tema, o qual, segundo eles, só poderia ser legitimamente regulado pelo Legislativo federal.

Um terceiro argumento de ordem secular apresentado por atores religiosos no debate público sobre direitos de gays e lésbicas seria elaborado, enfim, a partir da distinção entre laicidade e laicismo. Eles agenciam essa distinção para efetuar uma crítica interna do Estado secular, indicando um sentido próprio de laicidade. Para eles, Estado laico significaria, por exemplo, neutralidade em relação a todas as denominações e instituições religiosas, não uma disposição estatal contrária ao religioso no espaço público. Com Urbinati (2010; 
Marzano; Urbinati, 2013) podemos pensar, em contrapartida, que o Estado laico é um Estado neutro: não só diante das múltiplas instituições e expressões religiosas, mas também em relação aos que rejeitam qualquer religião e ou a sua influência sobre preceitos civis. Nesse sentido, a laicidade não implica a imposição de valores estatais à sociedade, nem um uso dogmático do secularismo, mas a garantia de um espaço de pluralidade religiosa pelo Estado e mesmo a liberação do indivíduo em relação à religião. O instrumento do Estado para tanto seria, no entender de Urbinati, o respeito e a atualização do ethos constitucional (Urbinati, 2010; Marzano; Urbinati, 2013).

Como afirmamos, esse ethos seria fundado na pluralidade e em direitos que asseguram aos indivíduos um espaço em relação ao poder público e às maiorias. Respeitá-lo e mantêlo atual implicaria, em síntese, um compromisso das instituições estatais com o predomínio da ética inscrita na Constituição sobre éticas concorrentes. É certo que sua prevalência pode ser contestada - e é o que acontece quando se apela, por exemplo, à precedência do cristianismo em relação a leituras seculares dos direitos humanos ou à sua influência na linguagem desses direitos -, mas o ethos constitucional tanto possibilita a construção das demandas de gays e lésbicas quanto garante a liberdade religiosa. Isso não significa que a opinião da maioria ou de atores políticos religiosos não possa ser contemplada em uma democracia constitucional em debates públicos sobre direitos; significa, porém, que sua demanda, formulada com uma gramática estrategicamente secular, afronta o princípio do Estado laico na medida em que transforma a lei em uma arma das maiorias, em lugar de escudo de minorias (Marzano; Urbinati, 2013), em tensão com religiões e religiosos.

\section{Referências}

BALLOUSSIER, Anna Virginia. Evangélicos farão marcha contra a homofobia na Parada Gay. Folha de São Paulo, 2015. Disponível em <http://www1.folha.uol.com.br/cotidiano/2015/06/1638621-evangelicos-farao-marchacontra-homofobia-na-parada-gay.shtml>. Acesso 20 dez. 2017.

BARBOSA, Olivia Alves. As tensões entre moral religiosa e o direito da pessoa na conformação das entidades familiares. São Paulo: FD-USP, 2017.

BRASIL. Congresso Nacional. Câmara dos Deputados. Audiência pública realizada em 24 de setembro de 2015 , na Comissão Especial destinada a proferir parecer ao PL 6.583/2013. Brasília, DF. 2015a.

BRASIL. Congresso Nacional. Câmara dos Deputados. Audiência pública realizada em 25 de junho de 2015, na Comissão Especial destinada a proferir parecer ao PL 6.583/2013. Brasília, DF. 2015b.

BRASIL. Congresso Nacional. Câmara dos Deputados. Relatório para a comissão especial destinada a proferir parecer do projeto de lei nº 6.583, de 2013. Relator: Diego Garcia. Brasília, DF. 2015c.

BRASIL. Congresso Nacional. Câmara dos Deputados. Relatório substitutivo para a comissão especial destinada a proferir parecer do projeto de lei no 6.583, de 2013. Relator: Ronaldo Fonseca. Brasília, DF. 2014. Disponível em: <http://www.camara.gov.br/proposicoesWeb/prop_mostrarintegra?codteor=1287153\&filename $=$ PRL +1 +PL658313+\%3D\%3E+PL+6583/2013>. Acesso em: 05 maio 2015.

BRASIL. Congresso Nacional. Câmara dos Deputados. Projeto de lei nº 6.583, de 2013. Autor: Andersson Ferreira. Brasília, DF. 2013a. Disponível em: < http://www.camara.gov.br/sileg/integras/1174113.pdf> Acesso em: 7 mar. 2018. 
BRASIL. Senado Federal. Projeto de lei no 470, de 2013. Brasília, DF. 2013b. Disponível em: < http://www. migalhas.com.br/arquivos/2014/1/art20140109-13.pdf> Acesso em: 7 mar. 2018.

BEYER, P. Socially engaged religion in a post-westphalian global context: remodelling the secular/ religion distinction. Sociology of Religion, v.73, n.2, pp.109-129, 2012.

BUTLER, Judith. O parentesco é sempre tido como heterossexual. Cadernos Pagu Campinas, v. 21, p. 219-260, 2003.

Problemas de gênero: feminismo e subversão da identidade. Rio de Janeiro: Civilização Brasileira, 2010.

CASTRO, Gabriel; MATTOS, Marcela.Vinde a mim os eleitores: a força da bancada evangélica no Congresso. Revista Veja, 23 de março de 2013. Disponível em: <https://veja.abril.com.br/politica/vinde-a-mim-os-eleitoresa-forca-da-bancada-evangelica-no-congresso/>. Acesso em: 21 dez. 2017.

CONSELHO FEDERAL DE PSICOLOGIA. Resolução CFP 01/99 é mantida em decisão judicial. 2017. Disponível em <http://site.cfp.org.br/resolucao-cfp-0199-e-mantida-em-decisao-judicial/>.Acesso em 21 dez. 2017.

DIP, Andrea. Bancada evangélica cresce e mistura religião e política no Congresso. Uol, 2015. Disponível em: $<$ https://noticias.uol.com.br/politica/ultimas-noticias/2015/10/19/bancada-evangelica-cresce-e-misturapolitica-e-religiao-no-congresso.htm>. Acesso em: $21 \mathrm{dez} .2017$.

FOUCALT, M. A História da sexualidade: a vontade de saber. Tradução de Maria Thereza da Costa Albuquerque e J. A. Guilhon Albuquerque. Rio de Janeiro: Graal, 1979.

FRASER, Nancy. Justice interruptus: critical reflections on the "postcolonialist" condition. New York-London: Routledge, 1997.

GIUMBELLI, E. Símbolos religiosos em controvérsias. São Paulo:Terceiro nome, 2014.

GOMES, E.;MENEZES, R.A.; NATIVIDADE, M. Proposições de leis e valores religiosos: controvérsias no espaço público. In: Valores religiosos e legislação no Brasil: a tramitação de projetos de lei sobre temas morais controversos. Rio de Janeiro: Garamond, 2009.

GLOBO PLAY. Padre Fábio de Melo fala sobre história de casal gay que batizou filhos adotados. Disponível em <https://globoplay.globo.com/v/5837787/>.Acesso em: 20 dez. 2017.

HABERMAS, Jürgen. Religion in the public sphere. European Journal of Philosophy, v. 1, n. 14, p. 1-25, 2006.

HURD, E. Beyond religious freedom: The New Global Politics of Religion. Princeton; Oxford: Princeton University Press, 2015.

MARZANO M.; URBINATI, N. Missione impossibile: la reconquista cattolica dela sfera pubblica. Bologna: Il Mulino, 2013. [E-book Kindle]

McCANN, Michael. Law and social movements: contemporary perspectives. Annual Review of Law and Social Sciences, v. 2, p. 17-38, dez. 2006.

MELLO, L. Novas famílias: conjugalidade homossexual no Brasil contemporâneo. Rio de Janeiro: Garamond, 2005.

MISKOLCI, Richard. Pânicos morais e controle social: reflexões sobre o casamento gay. Cadernos Pagu, Campinas, n. 28, p. 101-128, 2007.

A teoria queer e a sociologia: o desafio de uma analítica da normalização. Sociologias, ano 11, n. 21, pp. 150-182, 2009.

MONTERO, P. Controvérsias religiosas e esfera pública: repensando as religiões como discurso. Religião e Sociedade, Rio de Janeiro, v.32, n. 1, pp. 167-183, 2012.

Religião, laicidade e secularismo: um debate contemporâneo à luz do caso brasileiro. Cultura y Religión, v. 2, n. 2, pp. 13-150, 2013.

Religião, pluralismo e esfera pública no Brasil. Novos Estudos, n. 74, p. 47-65, 2006. 
MORETTI, Juliene. Evangélicos se manifestam contra o preconceito no Conjunto Nacional. Revista Veja, 2017. Disponível em:<https://vejasp.abril.com.br/cidades/evangelicos-parada-gay-cura-homofobia/>. Acesso em: 20 dez. 2017.

MOYN, Samuel. Christian human rights. Philadelphia: University of Pennsylvania Press, 2015

NAGAMINE, Renata ReverendoVidal Kawano. Direitos de identidade sexual: a não discriminação por orientação sexual no direito internacional. São Paulo: FD-USP, 2017.

PINHEIRO,D.A. R. Direito, Estado e religião: a constituinte de 1987/1988 e a (re)construção da identidade religiosa do sujeito constitucional brasileiro. Dissertação (Mestrado em Direito) - Universidade de Brasília. Brasília, 2008.

SANT’ANA, Raquel. O som da marcha; evangélicos e espaço público na marcha para Jesus. Religião e Sociedade, Rio de Janeiro, v. 34, n. 2, p. 210-231, 2014.

SILVA, V. A. La unión entre personas del mismo género: ¿cuán importantes son los textos y las istituciones? Discusiones, n. 15, 2, pp. 171-203, 2014.

TARROW, Sidney. O poder em movimento: movimentos sociais e confronto político. Tradução de Ana Maria Sallum. Petrópolis:Vozes, 2009.

TAYLOR, C. Uma era secular. São Leopoldo: Unisinos, 2010. Tradução de Nélio Schneider e Luiza Araújo.

TERRA. Padre Fábio de Melo defende união gay em seu Twitter. 2015. Disponível em < https://www.terra. com.br/noticias/brasil/padre-fabio-de-melo-defende-uniao-gay-em-seu-twitter,7bb23d03b2fac410VgnVCM3 000009af154d0RCRD.html>. Acesso em: 20 dez. 2017.

URBINATI, N. Laïcite in reverse: mono-religious democracies and the issue of religion in the public sphere. Constellations, v. 17, n. 1, p. 4-21, 2010.

. Democracy disfigured: opinion, truth, and the people. Cambridge-London: Harvard University Press, 2014.

UOL. "NÃO TEMAS”, diz deputado a Temer em oração com a bancada evangélica. 2016. Disponível em $<$ https://noticias.uol.com.br/politica/ultimas-noticias/2016/05/13/nao-temas-diz-deputado-evangelico-paratemer-em-oracao.htm>. Acesso em: $21 \mathrm{dez} .2017$.

VAGGIONE, J. M. Reactive Politicization and religious dissidence: the political mutations of the religious. Social Theory and Practice, v. 31, n. 2, p. 233-255, 2005.

. Sexualidad, religión y política en América Latina. In: CORREAA, Sonia; PARKER, Richard (Org.). Sexualidade e política na América Latina: histórias, interseções e paradoxos. Rio de Janeiro: ABIA, 2011.

WEEKS, Jeffrey. Sexuality and its discontents: meanings, myths and modern sexualities. London-New York: Routledge, 2002.

WESTON, K. Families we choose: lesbian, gay, kinship. New York: Columbia University Press, 1997.

ZYLBERSZTAJN, J. O princípio da laicidade na Constituição Federal de 1988. 2012. 248 f. Tese (Doutorado em Direito) - Universidade de São Paulo, São Paulo, 2012. 


\title{
Homosexuality, Religion, and Rights: The Controversy over the Family Statute in Brazil
}

\begin{abstract}
:
In this article we aim at analyzing discursive strategies and normative choices of congressmen that are formally or ideationally linked to so-called 'traditional churches' in the public debate about the bill n. 6.583/2013, popularly known as the Family Statute. The disputes between these political forces and secular political actors have found particularly fertile ground in the House of Representatives. Their differences, their limits, and the debates around the Family Statute allow us to reflect on the place of rights and religion in the Brazilian public space. To better apprehend the status of the religious in the Brazilian public space, we recur to an anthropological literature on religion, whereas to analyze the collected speeches, we use recent writings of Nadia Urbinati on the subject, discussed from the perspective of political theory. This article results from a qualitative research, developed through documental research and bibliographical review.
\end{abstract}

Keywords: sexual orientation, family law, democracy, human rights, judicial court.

\section{Homosexualidad, religión y derechos: la controversia sobre el Estatuto de la Familia en Brasil}

\section{Resumen:}

En este artículo, proponemos analizar las estrategias discursivas y normativas de diputados federales formal o idealmente vinculados a las llamadas "iglesias tradicionales" en el debate público sobre el proyecto de ley $\mathrm{n}^{\circ}$ 6.583, de 2013, conocido como Estatuto de la Familia. Observamos que las disputas entre esas fuerzas y actores políticos seculares han encontrado un terreno fértil en la Cámara de Diputados. Suponemos que las diferencias, potencialidades y el debate acerca del Estatuto de la Familia permiten reflexionar sobre el lugar de los derechos y la religión en el espacio público brasileño. Se recurre a una literatura antropológica sobre religión para comprender el estatuto del religioso en el espacio público brasileño y, para analizar las fallas recogidas, también se utilizan escritos recientes de Nadia Urbinati sobre el tema, que lo discute desde el dominio de la teoría política. Se trata de un artículo resultante de investigación cualitativa, que empleó como técnicas para recolección de datos la investigación documental y la revisión bibliográfica.

Palabras-claves: Orientación Sexual; Derecho de Familia; Democracia; Derechos Humanos; Corte Judicial. 